\title{
Ecodesign of Liquid Fuel Tanks
}

\author{
Jana Gicevska ${ }^{1}$, Gatis Bazbauers ${ }^{2}$, Mara Repele ${ }^{3},{ }^{1-3}$ Institute of Energy Systems and Environment, \\ Riga Technical University
}

\begin{abstract}
The subject of the study is a 10 litre liquid fuel tank made of metal and used for fuel storage and transportation. The study dealt with separate life cycle stages of this product, compared environmental impacts of similar fuel tanks made of metal and plastic, as well as analysed the product's end-of-life cycle stage, studying the waste treatment and disposal scenarios. The aim of this study was to find opportunities for improvement and to develop proposals for the ecodesign of $\mathbf{1 0}$ litre liquid fuel tank.
\end{abstract}

Key words - ecodesign, fuel tank, LCA, ReCiPe

\section{INTRODUCTION}

Product ecodesign is one way how sustainability principles can be promoted and embodied in the management of resources. The main aim of ecodesign is to consider environmental aspects during product design, thus improving the environmental performance of the product throughout its life cycle [1].

The subject of this research is a fuel storage tank. The origins of fuel tank production can be found in the 1930s. They were produced for the German army during the World War II [2].

Over 70 years, the design of military metal fuel has remained almost unchanged. Today cans of the same design are widely used primarily for fuel or water storage and transportation. Cans of various sizes and materials are available all over the world. Most of them are made of steel and plastic raw materials which are among the most studied materials as regards to impact on the environment [3, 4].

The metal industry is a very large industry and covers many other industries. In collaboration with metal industry scientists, the environment impacts of metal materials have been studied through all phases of their life cycle, focusing mainly on the metal extraction and product manufacturing phases $[5,6,7]$. They have proved that by improving these phases, the impact on the environment could be significantly reduced. Most of the studies are devoted to recycling of metal products, looking at the basic principles of an effective recycling process. The sustainable development of the metal industry, including cleaner production technologies, and examples of good practice have also been discussed and considered. However researchers point out that studies are still lacking on individual metal products and their impact on the environment $[8,9,10]$.

Studies on the environmental impact of polymers cover only certain life cycle stages, such as the production and processing stages of plastics. These life cycle stages create the major part of impact on the environment of the plastic products $[11,12,13,14]$.

\section{METHODS}

Life cycle assessment (LCA) is one of the most widely used tools in carrying out ecodesign [1].

LCA methodology is used to calculate and compare the product's potential impact on the environment. This study is based on ISO 14040 and ISO 14044 standards, which describe the four main evaluation procedures: (1) the goal and scope definition, (2) the life cycle inventory analysis, (3) the life cycle impact assessment, and (4) its interpretation [15, 16].

The software "SimaPro 7.2." faculty version was used to model environmental impacts caused during the product's lifecycle, while assessment of the environmental impact is done using the "ReCiPe" (2008) methodology [17, 18].

\section{GOAL AND SCOPE DEFINITION}

The goal of the research is to develop proposals for the ecodesign of a 10 litre metal can by performing a detailed life cycle assessment approach and studying the product's environmental impact throughout its life cycle, starting from the extraction of raw materials, including product manufacturing and transportation stages, and ending with the final phase of the life cycle. The life cycle assessment has been conducted to find out in which of the product's life cycle phases it is necessary and possible to make ecodesign improvements.

The study summarizes the inventory data of 2010 on the fuel can produced in Latvia, and the main raw material of the can is steel. Taking into account that fuel can also be stored in a can made from high density polyethylene (HDPE) material, a comparison of the potential environmental impact of the metal can with the plastic one is conducted in the study.

Inventory data for the life cycle of steel and plastic cans is largely based on assumptions. The data of both types of materials are modelled by using software "SimaPro 7.2." faculty version with the provided databases.

TABLE I

CHARACTERISTICS [20, 21]

\begin{tabular}{ccccc}
\hline $\begin{array}{c}\text { Material of } \\
101 \mathrm{can}\end{array}$ & $\begin{array}{c}\text { Mass } \\
(\mathrm{kg})\end{array}$ & $\begin{array}{c}\text { Life time } \\
\text { (years) }\end{array}$ & $\begin{array}{c}\text { Number of cans } \\
\text { according to FU }\end{array}$ & $\begin{array}{c}\text { Mass according } \\
\text { to FU (kg) }\end{array}$ \\
\hline Steel & 3.0 & 10 & 1 & 3.0 \\
\hline HDPE & 1.0 & 5 & 2 & 2.0 \\
\hline
\end{tabular}

The functional unit (FU) is a quantitative description of the product or service performance [19]. FU in this study is defined as follows: holding of $10 \mathrm{~L}$ liquid fuel for a 10 year 
life time. Table 1 summarizes the main characteristics of the fuel cans analyzed in the study.

The system boundaries are characterized by product-related life cycle phases that are not included in the study range [19]. The metal fuel can system boundaries included (see Fig.1): raw material extraction, delivery to the production plant, product manufacture, distribution and delivery to the consumer, as well as the end-of-life stage.

Taking into account that the use-phase of the product does not require extra energy or create negligible environmental impacts, the product's use phase is excluded from the system boundaries. The system boundaries of plastic can coincide with those of the metal can. The difference is that transportation of plastic raw materials is not taken into account, because no data were available about possible transportation distances, since the factory does not produce plastic cans.

To avoid inaccurate assumptions that affect the final results of the study, the flows which cannot be readily defined or which have the insufficient information (e.g. tools used by employees) are not included in the product system boundaries.

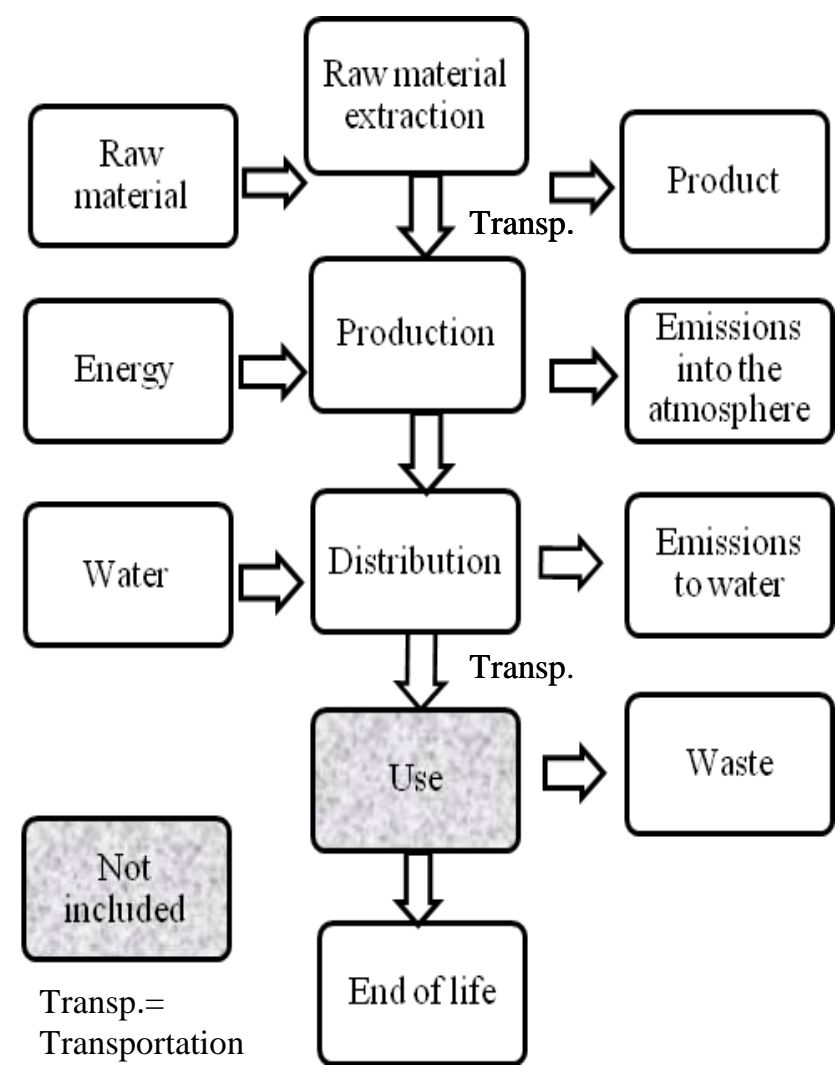

Fig. 1. The system boundaries of a metal can.

The main assumptions of the study are as follows:

- Transport logistics are planned so that the transport is fully loaded, without an empty cargo carriage;

- The distance for the transportation of raw materials and product shipments within the territory of Latvia is $200 \mathrm{~km}$;
- At the end-of-life cycle stage, metal and plastic cans and packaging are land-filled or recycled;

- At the end-of-life cycle stage, cans are clean and unpolluted.

\section{RESULTS}

The assessed environmental impact of the metal fuel tank created by the production phase is 1.06 points $(\mathrm{Pt})$. The research of the metal can manufacturing phase has revealed that, out of eight processes included in the study, the greatest impact on the environment is created by the steel cutting and stamping processes. These processes account for $62 \%$ of the total impact of the manufacturing phase. Serious contributions to the environmental impact are added by painting (10\%), welding $(8 \%)$ and the surface treatment (cleaning) process $(6 \%)$. The impact of the cutting and stamping processes is caused by the steel consumption and raw material extraction processes. The environmental impact caused by the painting, surface treatment (cleaning) and welding processes, however, is due to heat and electricity consumption. The emissions into air (such as $\mathrm{PM}_{10}$, VOCs) created during these processes play a significant role.

The three most important factors creating environmental impact in relation to the production phase of the metal cans are the use of (1) coal and (2) natural gas, since a great impact is caused by obtaining and burning of those resources with the aim to produce electricity and heat, as well as (3) iron ore extraction, since the main raw material of the fuel tank is steel.

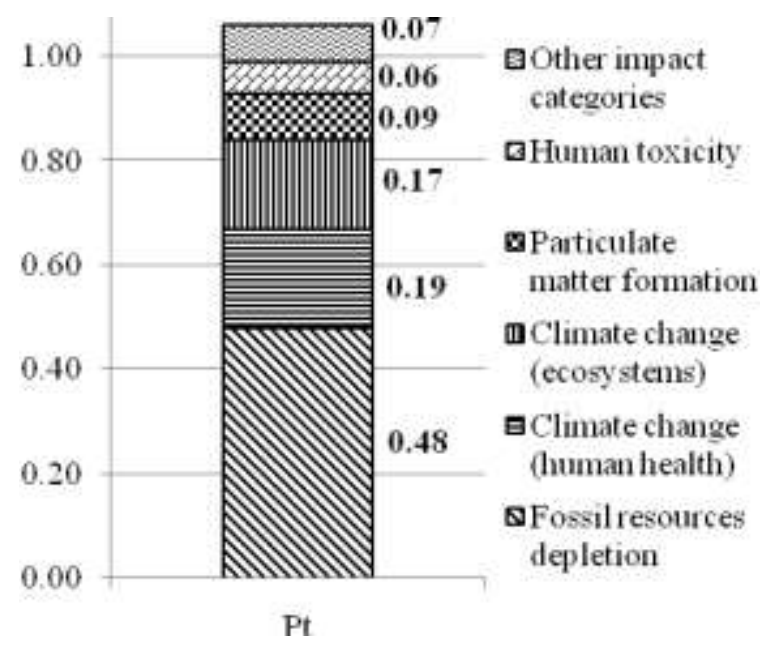

Fig. 2. Affected impact categories in metal can's production phase.

Consequently, the most affected impact category in the production phase is the depletion of fossil resources which makes up a $45 \%$ share of the total environmental impacts of all categories. Due to emissions from the coal and natural gas combustion processes, a significant impact on the environment is defined in the categories - climate change (human health) $18 \%$ and climate change (ecosystems) 16\%. Considerable impact on the environment is determined in the categories particulate matter formation (8\%) and human toxicity $(6 \%)$, because the impact generated in these categories is associated 
with the substances used in welding, painting and surface treatment processes, which generate VOC and $\mathrm{PM}_{10}$ emissions (see Fig.2).

A sensitivity analysis, comparing effect on the environmental impact of different parameters, such as the consumption of raw materials, heat and electricity during the production phase, shows that the overall environmental impact indicator is affected mostly by raw material consumption. If consumption of the raw materials used for production is reduced by $20 \%$, the overall environmental impact of production can be reduced by $11 \%$.

Environmental impact of the product transport phase is 0.14 points and the main cause of this impact is crude oil extraction (around $47 \%$ share of the total impact of factors), as well as emissions during the transportation (28\%). The most sensitive impact categories during the transport stage are fossil fuel depletion (54\%), climate change (human health) (19\%), climate change (ecosystems) (17\%) and particulate matter formation $(5 \%)$. These categories are related to crude oil extraction and use of fuel.

The recycling of metal creates an impact of 0.76 points, while disposal in landfill -1.20 points. The main factors which contribute to the environmental impact of recycling are transportation by truck - $49 \%$ of the total impact, as well as the processes associated with the preparation of scrap metal - 5\% of the total impact.

The factors that have significant environmental impact in the metal product disposal scenario are transportation by truck - $45 \%$ of the total impact and disposal of packaging - $12 \%$ of the total impact. These factors determine the most sensitive impact categories, and, in the recycling scenario, that is natural land transformation, while the product disposal in landfill leads to fossil fuel depletion.

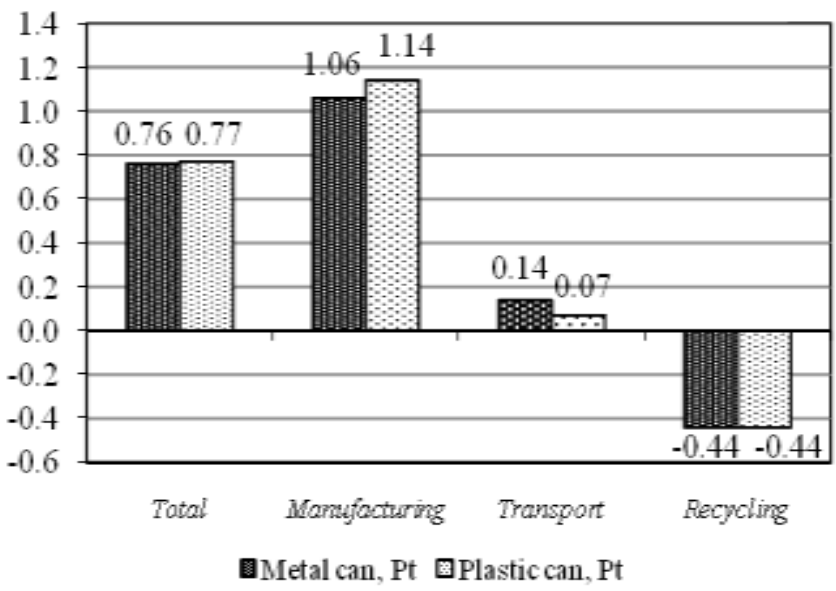

Fig. 3. Comparison of the life-cycle impact with a recycling scenario for metal and plastic cans

When the environmental impact of metal and polymermaterial products for a 10 year life time are compared, it has been found that the total environmental impact for the recycling scenario is similar, i.e. 0.77 points for the plastic can and 0.76 points for the metal can (see Fig. 3 ).
The total impact on the environment is greater, if the product is land-filled at the end of its life cycle, respectively 1.23 points for the plastic can and 1.20 points for the metal one (see Fig. 4).

Two important conclusions are drawn from the above results: first, although the recycling process generates impact on the environment, disposal in landfill is the worst scenario for both products. Secondly, the overall environmental impact throughout the life time for both products depends considerably on the product end-of-life scenario.

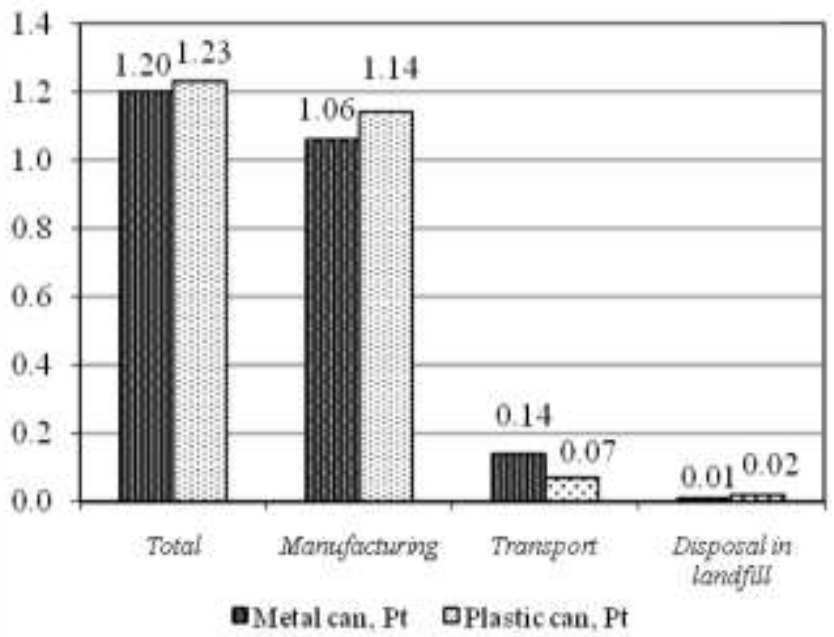

Fig. 4. Comparison of the life-cycle impact with landfill disposal scenario for metal and plastic cans.

If the plastic and metal fuel tanks are recycled, the overall environmental impact of the product is reduced by approximately $37 \%$ (slightly more for the metal can).

The choice of an appropriate life time when defining the functional unit plays an important role when making a comparison of the metal and plastic products, since, as shown by the results, the manufacture of a single metal can which serves 10 years causes less impact than the manufacture of two plastic cans which serve the same life time.

The environmental impact created during transportation of the product depends on the transported mass and distance. When the transportation impacts of the plastic and metal cans are compared, it was determined that the metal can with a larger mass results in a two times greater impact, i.e. 0.14 points compared to 0.06 points of the plastic can.

The end-of-life cycle impact of metal and plastic cans is equal -0.44 points, if the products are recycled (see Fig. 3). If the plastic or metal product is disposed in landfill, the difference of the environmental impact is two times (see Fig. 4).

The major "ReCiPe" (2008) damage category on the environment at the endpoint level is created by the use of fossil fuel for both product materials (see Fig. 5). It should be noted that the plastic product impact category - use of fossil fuel - in both life cycle scenarios assessed at a higher indicator value than for the metal can. 


\section{CONCLUSIONS}

The conclusion describes ecodesign proposals for the improvement of the metal fuel tank. Impact on the environment created during the product's manufacturing phase could be reduced by considering the following principles:

- Resource savings in production processes. In the product's manufacturing phase, a variety of resources is used. For example, heat energy is used to provide for production processes and to heat the rooms, but electricity is necessary for equipment operation, lighting and ventilation. Water is used for surface treatment (degreasing and etching) processes and for equipment cooling in the welding process. In addition, the quality of the product is tested by soaking cans in water tanks. Chemicals are used in the surface treatment process. Heat consumption can be reduced by insulating production buildings. Electricity consumption can be reduced by using production equipment with higher energy efficiency, such as modern press forms.
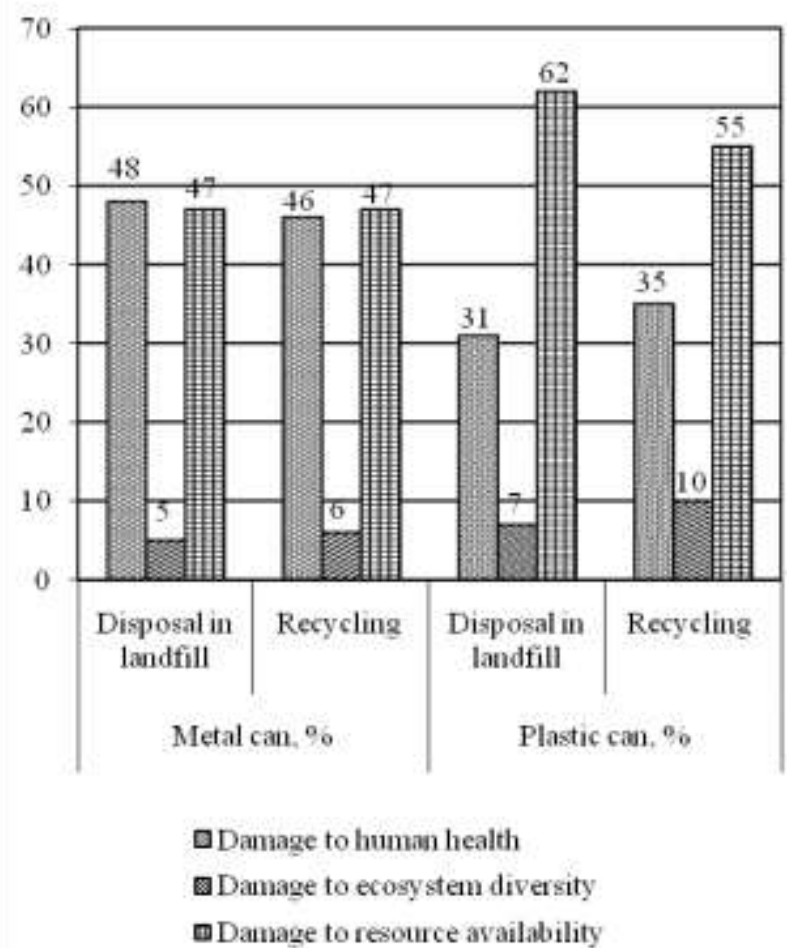

Fig. 5. Comparison of life-cycle impact categories at the endpoint level for metal and plastic cans.

- Replacement of hazardous substances with less hazardous ones. Various hazardous substances, such as orthophosphoric acid, wet paint, butanol, etc., are used in the production stage. These substances must be replaced with less hazardous ones. For example, replacement of wet paints with powder paints could reduce the product's impact on the environment.

- Product's quality improvement. The surface treatment of the metal can (etching) is performed with the aim to treat its surface from contamination, thus later avoiding low quality paint coatings. The maximum efficiency of the above mentioned process and other manufacturing processes will ensure a longer product life time and avoid the manufacturing of a new product and, thus also the impact on the environment connected to its manufacture. The product's life time will increase with the use of qualitative chemicals and paints.

- Product's management quality improvement. Using more effective quality control methods during the manufacturing process could reduce defective production and improve the overall quality of the product. For example, quality requirements for the large and small can components should be checked before the can is welded.

- Improvement in technological processes or cleaner production. By following this principle, emissions to air, water and soil can be reduced. Process heat is produced by burning natural gas. The replacement of natural gas with renewable energy sources (e.g. biomass) could significantly reduce the product's impact on the environment.

- Reduction of production residues. The product's manufacturing process generates a variety of waste material. Using materials in a more effective way, the overall material consumption per one product unit would be reduced. This could be accomplished by optimizing the form of stamping blanks, thus reducing scraps from metal stamping.

- Reduction of material consumption. Improving the design of cans, optimizing shape and strengthening by more effective ribs, which are designed on the can's both sides. The manufacturer must look at the possibility to reduce thickness of the used metal, at the same time avoiding decreasing the can's strength. It is also recommended to look at the possibility of using one handle, instead of three handles, for the fuel can. Both these optimizations will reduce the material consumption per one can.

- Manufacturing process automation. Introduction of new automated technologies in the manufacturing process would reduce the need for human labour. For example, automation of the welding process would improve accuracy of the welding, as well as efficiency and speed, thus saving the electricity used in this process.

- Qualifications and capacity improvement of employees. Human work has an important role in the manufacturing process. Human work is used in the welding process, as well as for controlling the dyeing process. Educating employees about saving resources and about the efficiency of the production process, as well as other environmental issues, would improve the product's environmental performance.

The impact on the environment in the product's transportation stage could be improved by considering the following principles:

- Preference to transport with smaller environmental impact. Transportation of raw materials for the production of cans to the production plant and delivery of the finished products to consumers is needed. The 
product's impact on the environment in the transportation stage would be reduced, if transport with less of an environmental impact is used. For example, the use of Euro 5 standard trucks, which cause fewer emissions into the atmosphere, would reduce the environmental impact.

- Reduction of transportation distances of raw materials. Raw materials are purchased in different countries. Impact on the environment could be reduced, if transportation distances are taken into account and materials are bought at sites closer to the production plant.

- Reduction of cargo weight. When supplying the production plant with raw materials or transporting the finished product, the producer must consider the reduction of the weight of packaging. If the cargo is transported with less weight, then fuel consumption is reduced and less impact on the environment is caused.

Impact on the environment in the product end-of-life stage could be improved by considering the following principles:

- Environmentally responsible product material selection. The environmental impact of the product's end-of life cycle stage can be reduced, if the materials used in the product manufacturing stage could be recycled with existing recycling technologies. It is also important to choose the materials which can be recycled with less impact on the environment.

\section{REFERENCES}

1. Plouffe, S., Lanoie, P., Berneman, C., et.al. Economic benefits tied to ecodesign. Journal of Cleaner Production, 2011, Nr.19, p. 573.-579.

2. Richard, M. D. The Little Can That Could. Invention and Techlology magazine, 1987, Nr.2, p. 3.

3. Reck, K.B., Chanbon, M., Hashimoto, S., et.al. Global Stainless Steel Cycle Exemplifies China's Rise to Metal Dominance. Environmental Science \& Technology, 2010, p.1.-7.

4. Norgate, E. T., Jahanshahi, S., Rankin, J. W. Assessing the environmental impact of metal production processes. Journal of Cleaner Production, 2007, Nr.15, p. 838.-848.

5. Morrs, M.H.E., Mulder, F.K., Vergragt, J.P. Towards cleaner production: barriers and strategies in the base metals producing industry. Journal of Cleaner Production, 2005, Nr.13, p. 657.-668.

6. Ingarao, G., Lorenzo, Di R., Micari, F. Sustainability issues in sheet metal forming processes: An overview. Journal of Cleaner Production, 2010, p. 1.-11.

7. Seppälä, J., Koskela, S., Melahen, M., et.al. The Finnish metals industry and the environment. Elsevier. Resources, Conservation and Recycling, 2002, Nr.35, p. 61.-67.

8. Dubreuil, A., Young, B.S., Atherton, J., et.al. Metals recycling maps and allocation procedures in life cycle assessment. Life Cycle Management, 2010, Nr.15, p. 621.-634.

9. Johanson, T.M., Söderstörm, M. Options for the Swedish steel industry - Energy efficiency measures and fuel conversion. Energy, 2010, p. 1.-8

10. Production of metal products [Online]. - [Accessed 18.01.2011.] Available:

http://www.cleanerproduction.com/directory/sectors/subsectors/metalpro dcts.html

11. Waste polymaterials [Online]. - [Accessed 18.01.2011.]. Available: http: //www.atkritumi.lv/apraksts.php?id=21\%C2\%AEion=1\&kid=13

12. Salem, M.S., Lettieri, P., Baeyens, J. Recycling and recovery routes of plastic solid waste (PSW): A review. Waste Management, 2009, Nr.29, p. $2625 .-2643$

13. O'Neill, T.J. Life Cycle Assessment and Environmental Impact of Plastic Products. 2003. 134 p.
14. Rives, J., Rieradevall, J., Gabarrell, X. LCA comparison of container systems in municipal solid waste management. Elsevier. Waste Management, 2010, Nr. 30, p. 949.-957.

15. International Standard ISO 14044. Environmental management - life cycle assessment - Requirements and guidelines International. 2006.

16. International Standard ISO 14040. Environmental management - life cycle asessment - Principles and Framework. 2006

17. SimaPro [Online]. - [Accessed 12.02.2011.]. Available: www.pre.nl

18. Goedkoop, M., Heijungs, R., Huijbregts, M., et.al. ReCiPe 2008. A life cycle impact assessment method which comprises harmonised category indicators at the midpoint and the endpoint level, First edition Report I: Characterisation. 2009, 132 p.

19. Rebitzer, G., Ekvall, T., Frischknecht, R., et.al. Life cycle assessment, Part 1: Framework, goal and scope definition, inventory analysis, and applications. Elsevier. Environment International, 2004, Nr.30, p.701.720

20. Fuel cans [Online]. - [Accessed 26.04.2011.]. Available: http://www.rocketcityrockcrawlers.com/memberstuff/al/Jerry\%20Can\% 20Paper\%20V1.3.pdf

21. Manuilova, A. Life Cycle assessment of industrial packaging for chemicals. Master thesis. Environmentally sustainable process technology, Akzo Nobel Surface Chemistry $\mathrm{AB}$ and Chalmers University of Technology: Chalmers University of Technology, 2003, 56 p.

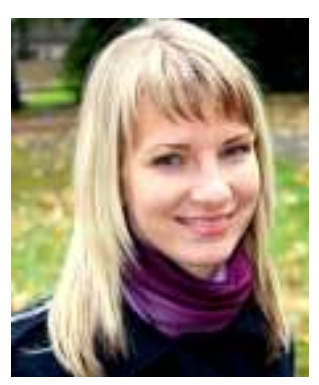

Jana Gicevska, Msc., has Bachelor Degree in Environmental Sciences (2009) at the faculty of Geography and Earth Sciences at University of Latvia, and Master Degree in Environmental Sciences (2011) at the Institute of Energy Systems and Environment at Riga Technical University. Research interests: ecodesign, life cycle assessment

Address: Kronvalda blvd. 1, LV-1010, Riga, Latvia E-mail: jana.gicevska@gmail.com

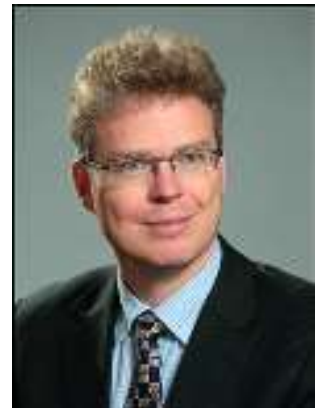

Gatis Bazbauers, Dr.sc.ing., has a diploma of thermal engineering (1990), master of science degree in mechanical engineering (1995), doctor of science degree in engineering (1999) and bachelor's degree in business administration (2002). He works in the Institute of Energy Systems and Environment, Faculty of Energy and Electrical Engineering at Riga Technical University from the year 2000, and currently is a Professor. He worked as a Managing Director in the energy company "Vattenfall Latvia" (19952007), as a Project Manager in the energy consulting company "EEE" (1992-1993) and as an Assistant in the Riga Technical University (19901993). The main research interests are district heating systems and cogeneration, energy system planning and economics, renewable energy sources, ecodesign, life cycle assessment. Gatis Bazbauers is a member of the council of Latvia's District Heating Association.

Phone: +371 67089911

E-mail: gatis.bazbauers@rtu.lv

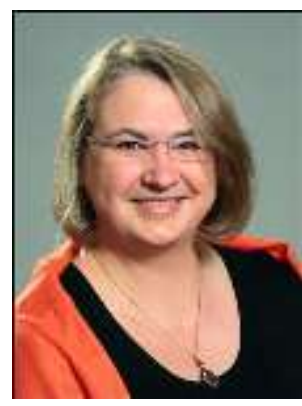

Mara Repele, $\mathrm{PhD}$ student of the Institute of Energy Systems and Environment at Riga Technical University, has Master Degree in Geology (2004) and Master Degree in Environmental Science (2009). The main field of study is ecodesign and life cycle assessment of building materials. Mara Repele currently works as a Forensic Scientist at the Biological and Chemical Investigation Department at the State Forensic Science Bureau, 55 Hospitalu Street, Riga, Latvia. Previously she worked as a Geologist at the Institute of Geology and as a Technician at the Laboratory of Rock Research at the University of Latvia. Mara Repele received the Letter of distinction of the Rector of the University of Latvia for researches in geology (2004) and Werner von Siemens Excellence Award for Master's thesis "Development of method for eco-design" (2009).

E-mail: mara.repele@rtu.lv 


\section{Jana Gičevska, Gatis Bažbauers, Māra Rēpele. Šķidruma uzglabāšanas tvertnuu ekodizains.}

Pêtītais produkts ir šķidruma uzglabāšanas tvertne jeb degvielas kanna, kuras lietošanas pirmsākumi meklējami 20.gs. 30 gados, kad to pirmo reizi sāka ražot vācu armijas vajadzībām II Pasaules kara laikā. Vairāk nekā septiṇdesmit gadus militāro metāla kannu dizains ir palicis gandrīz nemainīgs. Mūsdienās pēc līdzịga parauga ražotās civilās kannas ir pasaulē plaši lietots produkts, ko izmanto galvenokārt degvielas un ūdens uzglabāšanai un transportēšanai.

Darba mērḳis ir izstrādāt priekšlikumus 10 L kannas ekodizaina uzlabojumiem, izmantojot detalizētu dzīves cikla novērtējuma pieeju, un nosakot produkta ietekmi uz vidi visā tā dzīves ciklā, sākot ar izejvielu ieguvi, iekḷaujot produkta ražošanas un transportěšanas posmus, un beidzot ar dzīves cikla beigu posmu. Darba gaitā apskatīiti atsevišḳi šĩ produkta dzīves cikla posmi, veikts analogu degvielas tvertnuu, izgatavotu no metāla un pla stmasas, radīto ietekmju uz vidi salīdzinājums, kā arī pievērsta uzman̄̄ba produkta dzīves cikla beigu posmam, apskatot atkritumu pārstrādes un noglabāšanas scenārijus attiecībā uz ietekmi uz vidi. Dzīves cikla novērtējums veikts saskañā ar ISO 14044 un ISO 14040 standartiem, izmantojot programmatūru „SimaPro 7.2”, fakultātes versiju. Vides ietekmju novērtēšana veikta pēc „ReCiPe” (2008) metodoloǵijas. Dzīves cikla novērtējuma rezultāti sniedz priekšstatu par produkta būtiskākajām ietekmēm dzīves cikla laikā. Rezultāti izmantoti produkta ekodizaina priekšlikumu izstrādei, kas sekmē produkta vides snieguma uzlabošanu. Pētījuma mērḳauditorija ir produkta veidotāji, zinātnieki un studenti. 